\title{
Projecting the future ecological state of lakes in Denmark in a 6 degree warming scenario
}

\author{
Dennis Trolle ${ }^{1,2, *}$, Anders Nielsen ${ }^{1,3}$, Jonas Rolighed ${ }^{1}$, Hans Thodsen ${ }^{1}$, \\ Hans E. Andersen ${ }^{1}$, Ida B. Karlsson ${ }^{4}$, Jens C. Refsgaard ${ }^{4}$, Jørgen E. Olesen ${ }^{2,3}$, \\ Karsten Bolding ${ }^{1}$, Brian Kronvang ${ }^{1}$, Martin Søndergaard ${ }^{1}$, Erik Jeppesen ${ }^{1,2}$ \\ ${ }^{1}$ Department of Bioscience, Aarhus University, Vejlsøvej 25, 8600 Silkeborg, Denmark \\ ${ }^{2}$ Sino-Danish Centre for Education and Research (SDC), Beijing, PR China \\ ${ }^{3}$ Department of Agroecology, Aarhus University, Blichers Allé 20, 8830 Tjele, Denmark \\ ${ }^{4}$ Geological Survey of Denmark and Greenland (GEUS), Øster Voldgade 10, 1350 Copenhagen, Denmark
}

\begin{abstract}
Lakes are highly sensitive to climate change, and climate warming is known to induce eutrophication symptoms in temperate lakes. In Denmark, climate is projected to cause increased precipitation in winter and increased air temperatures throughout the year by the end of the 21st century. Looking further into the future, the warming trend is projected to continue and likely reach a $6^{\circ} \mathrm{C}$ increase around the 22nd century (relative to a baseline period of 1986-2005). In the present study, we evaluate the consequences of such extreme changes for temperate Danish lakes. We use a multifaceted modelling approach by combining an eco-hydrological model to estimate future water runoff and catchment nutrient exports with both mechanistic and empirical lake models, describing key biogeochemical indicators in lakes, in order to quantify the effects of future nutrient loads and air temperature on lake ecosystems. Our model projections for the future scenario suggest that annual water runoff will increase $(46 \%)$, driving also increases in exports of nitrogen and phosphorus (13 and $64 \%$, respectively). Both the mechanistic and empirical modelling approaches suggest that phytoplankton biomass will increase and that potentially toxin-producing cyanobacteria may become a dominant feature of the phytoplankton community from spring. Warming and increased nutrient loads also affect the food webs within the lakes in the direction of higher fish control of algae-grazing water fleas, further reinforcing eutrophication. To be able to mitigate these eutrophication effects, external nutrient loading to the lakes must be reduced considerably.
\end{abstract}

KEY WORDS: Extreme warming $\cdot$ Impacts $\cdot$ Lakes

\section{INTRODUCTION}

Lakes are highly sensitive to climate change (Williamson et al. 2008). In Denmark, the projected climate change in this century suggests, on balance, increased precipitation in winter months, and consequently a higher export of nutrients from catchments to lakes (Andersen et al. 2006, Jeppesen et al. 2009, 2011). This may enhance eutrophication and the risk of dominance by potentially toxin-producing cyanobacteria

${ }^{*}$ Corresponding author: trolle@bios.au.dk
(Trolle et al. 2014). These algae are further stimulated by higher temperatures (i.e. the kind of temperature expected in the future) (Kosten et al. 2012), and summer heat waves are known to favor blooms of potentially harmful cyanobacteria (Jöhnk et al. 2008).

Climate impact studies have typically been carried out using moderate emission scenarios such as A1B, yielding a projected warming of $2^{\circ}$ to $3^{\circ} \mathrm{C}$ by 2100 relative to present time (van der Linden \& Mitchell 2009). In its 5th assessment report, the Intergovern-

() The authors 2015. Open Access under Creative Commons by Attribution Licence. Use, distribution and reproduction are unrestricted. Authors and original publication must be credited. 
mental Panel for Climate Change (IPCC) noted that the present emissions follow a trajectory that is on or above the RCP8.5 scenario, leading to a likely global warming between $2.6^{\circ}$ and $4.8^{\circ} \mathrm{C}$ for the period 2081-2100 compared to 1986-2005 (Collins et al. 2013). However, the warming will continue beyond 2100, and the expected (global mean) temperature increase under the Representative Concentration Pathway scenario RCP8.5 by $2181-2200$ is $6.5^{\circ} \mathrm{C}$, with a likely range between $3.3^{\circ}$ and $9.8^{\circ} \mathrm{C}$, rising even further by 2300 . Hence, as long as the current emissions continue to increase, there is a global warming potential equivalent to $6^{\circ} \mathrm{C}$, either before or, most likely, shortly after 2100 (Christensen et al. 2015, this Special). In the present study we evaluate the consequences of such extreme changes for temperate Danish lakes. In this context, Christensen et al. (2015) analyzed to what extent the actual projected RCP emission scenarios (van Vuuren et al. 2011) reach the same temperature level as the $6^{\circ} \mathrm{C}$ scenario. They found that 8 out of 9 model runs for the RCP8.5 scenario reached a $6^{\circ} \mathrm{C}$ warming before 2300. This indicates that even though a $6^{\circ} \mathrm{C}$ warming seems unlikely within the present century (Collins et al. 2013), it is plausible and very likely to occur at some time if the present level of emissions continues.

It is evident from empirical space-for-time studies (Meerhoff et al. 2012, Jeppesen et al. 2014) and studies of effects of extreme events, such as heat waves and severe precipitation (Jöhnk et al. 2008, Elliott 2010 ), that a $6^{\circ} \mathrm{C}$ warming scenario could have drastic effects on ecosystem functioning, ecological state and water quality of lakes. However, no studies relating to the impacts on lakes of such high-end climate change scenarios have yet, to the best of our knowledge, been reported in the literature.

In the present study, we elucidate the potential consequences of an extreme climate warming scenario on lake ecosystems by applying 2 different mechanistic ecosystem models to 4 different Danish temperate lakes, and by the use of existing and new empirical regression models describing relations between temperature and nutrient loads, and key biological indicators based on a dataset comprising 909 Danish lakes (and up to 1270 lake years).

\section{METHODS}

\subsection{Climate scenarios}

The climate change scenario used is a $6^{\circ} \mathrm{C}$ warming scenario generated by perturbing a $1 \% \mathrm{CO}_{2}$ increase every year onto a climate model until the response reaches $6^{\circ} \mathrm{C}$. It is therefore not a truly projected $\mathrm{CO}_{2}$-emission scenario as those reported in the IPCC reports (e.g. Nakicenovic et al. 2000), but rather an artificially created climatic state. The emission scenario was run in the global and regional climate model (GCM-RCM) coupling of ECEARTHHIRHAM (Christensen et al. 2007, Hazeleger et al. 2012). After reaching a $6^{\circ} \mathrm{C}$ increase in air temperature relative to a baseline period comprising the years 1986-2005, the $\mathrm{CO}_{2}$ concentration was held constant, while the model was run for an additional $29 \mathrm{yr}$. This period was then used as a representation of the future period, for convenience referred to as 20712099, although it may occur at another point in time. Further information on the climate model can be found in Christensen et al. (2015). Due to scale differences and climate model biases, the GCM-RCM output needs to be downscaled and bias corrected before it can be used to force hydrological and lake models. In this study, data were downscaled using the Distribution Based Scaling method (Piani et al. 2010) for precipitation data, and the bias removal approach (Seaby et al. 2013) for temperature data. The historical control period was set to 1991-2005 (for which observation data were readily available), and the downscaling was performed on a grid basis for all variables. Further information about the applied downscaling/bias correction methods is provided by Seaby et al. (2013) and Karlsson et al. (2015, this Special). For simplicity, and also as not all the lake models used in this study are able to account for climate forcing other than temperature, the future climate scenarios where generated through changes to air temperatures and precipitation alone (the latter for quantifying water and nutrient runoff), which we assume are the main drivers of changes in hydrology and nutrient dynamics, thus disregarding any changes that may occur in other meteorological variables.

For projections of the potential future state of Danish lake ecosystems, we take advantage of a range of mechanistic aquatic ecosystem model applications, which have previously been applied and undergone adaptation and rigorous testing with 4 Danish lakes, and also well-established empirical regression models supplemented with a few models of recent origin between biological indicators and temperature and nutrient loads (Table 1). These models have been set up to reflect certain, and somewhat differing, time periods, but all within the climate baseline period. To utilize the entire but differing time periods that these models represent (including preservation of the nat- 
Table 1. Basic description of lakes used in the analysis: mechanistic modelling (4 lakes) and an empirical modelling approach

\begin{tabular}{|lcccc|}
\hline Lake & $\begin{array}{c}\text { Model application } \\
\text { period }\end{array}$ & $\begin{array}{c}\text { Mean depth } \\
(\mathrm{m})\end{array}$ & $\begin{array}{c}\text { Surface area } \\
\left(\mathrm{km}^{2}\right)\end{array}$ & References \\
\hline Lake Ravn & $1989-2002$ & 15 & 1.8 & Trolle et al. (2008a,b) \\
Lake Arreskov & $1990-2010$ & 1.9 & 3.2 & $\begin{array}{l}\text { Nielsen (2013), Nielsen et al. (2014) } \\
\text { Rolighed (2013), Rolighed et al. } \\
\text { Lake Søbygaard }\end{array}$ \\
$\begin{array}{l}\text { (unpubl. data) } \\
\text { Lake Engelsholm }\end{array}$ & $1990-2010$ & 1.1 & 0.38 & $\begin{array}{l}\text { Trolle et al. (2014) } \\
\text { Jeppesen et al. (2009) (unpubl. data) }\end{array}$ \\
\hline
\end{tabular}

Table 2. Scenarios (SC) simulated for the 4 lake case studies (see Table 1) using mechanistic ecosystem models. Air temperature was used as the primary determinant for scenarios simulated by the lake ecosystem models (i.e. median, 10th and 90th percentiles [pctl] of daily air temperature time series), whereas downscaled precipitation data were only used as a baseline mean $\left(750 \mathrm{~mm} \mathrm{yr}^{-1}\right)$ and future mean $\left(931 \mathrm{~mm} \mathrm{yr}^{-1}\right)$ by the SWAT model to generate estimates of future nutrient exports (SC7-9)

\begin{tabular}{|llcl|}
\hline Scenario & Climate data & Annual mean air temperature $\left({ }^{\circ} \mathrm{C}\right)$ & External nutrient load data \\
\hline SC1 & Base (median) & 8.6 & Base \\
SC2 & Base (10 pctl) & 5.3 & Base \\
SC3 & Base (90 pctl) & 11.4 & Base \\
SC4 & Future (median) & 13.9 & Base \\
SC5 & Future (10 pctl) & 11.2 & Base \\
SC6 & Future (90 pctl) & 16.4 & Base \\
SC7 & Future (median) & 13.9 & Monthly changes (SWAT-estimated) \\
SC8 & Future (10 pctl) & 11.2 & Monthly changes (SWAT-estimated) \\
SC9 & Future (90 pctl) & 16.4 & Monthly changes (SWAT-estimated) \\
\hline
\end{tabular}

ural year to year variation in external nutrient loads), we derived annual time series of a national average daily air temperature for both the baseline and future climate periods, based on the climate model simulation. In total, a series including 6 annual time series with daily data was generated, representing the median, 10th and 90th percentile of daily air temperatures for the baseline and future periods (Table 2). In creation of baseline and future scenarios, these yearly time series of daily air temperatures were applied and repeated for the entire duration of the original lake model applications.

\subsection{Eco-hydrological modelling for nutrient export estimates}

In addition to direct climate effects on lakes represented by changes in air temperature, we derived an additional scenario where both temperature forcing and future nutrient loads are changed. The semidistributed SWAT model (Soil and Water Assessment Tool) by Arnold et al. (1998) has recently been applied to the entire island of Funen, Denmark (Thodsen et al. unpubl. data). This set-up was utilized to obtain an indication of potential future changes in nutrient exports from Danish catchments, which may eventually contribute to the loading of downstream lakes. We generated a single future water runoff and nutrient export scenario to be combined with the multiple scenarios of future climate warming. The changes in hydrology and nutrient exports in the future scenario are here influenced only by changes in air temperature and precipitation from the climate change scenario. We do acknowledge that other factors, and in particular land use management, will likely change considerably with climate (Olesen et al. 2011), and thus this will ultimately also shape the response of catchment hydrology and nutrient exports to climatic changes. In our study, however, we are interested in an overall indication of the magnitudes by which seasonal nutrient exports could change. An ecohydrological model such as SWAT, set up to represent the current Danish landscape and land uses, can provide just that. Also, given the relatively small geographical extent of Denmark, and the fact that the island of Funen is to some extent representative of the median climate in Denmark in terms of net precipitation (precipitation minus evapotranspiration; e.g. Henriksen et al. 2003), we assume that 
model simulations of Funen provide a reasonable indicator for the behavior of other regions in Denmark. The catchment of the entire island of Funen $\left(3528 \mathrm{~km}^{2}\right)$ was delineated by SWAT into 115 subbasins and 7685 Hydrological Response Units (HRUs). Followed by a warm-up period (model spinup) for 5 yr (1995-1999), SWAT was calibrated for discharge and total nitrogen (TN) and total phosphorus (TP) exports from 11 individual sub-basins scattered throughout Funen for the 6 yr period 2000-2005, and subsequently validated for the $4 \mathrm{yr}$ period 2006-2009. Further details on the SWAT application are provided by Thodsen et al. (unpubl. data). For simplicity, the climate change scenario simulated by SWAT was implemented by a monthly mean delta change factor for air temperature and precipitation derived from the mean future climate change scenario period relative to the baseline period (where data for the future period was downscaled as described above). The monthly delta change factors were applied to the period on which all required input data for SWAT was available (19902009) using a 10 yr warm-up period followed by a $10 \mathrm{yr}$ period for which the results were extracted and compared between the baseline and future climate scenario. Monthly average changes in the export of TN and TP were extracted and subsequently applied in additional lake ecosystem scenario simulations (Table 1).

\subsection{Mechanistic ecosystem modelling}

Mechanistic aquatic ecosystem models have previously been applied and have undergone rigorous testing on 4 Danish lakes (Table 1). This includes the PCLake model (Janse 1997) adapted to 3 shallow lakes (Lakes Arreskov, Søbygaard, and Engelsholm) and the DYRESM-CAEDYM model (Hamilton \& Schladow 1997) adapted to a deep lake (Lake Ravn). Both model types have built in the effect of temperature (and nutrient loads) on a wide range of ecosystem processes, including, for example, mineralization rates of organic matter, growth rates specific for individual phytoplankton groups, sediment oxygen demand, etc. While differing somewhat in the conceptual basis (see Mooij et al. 2010 and Trolle et al. 2014 for details), including how temperature shapes particular processes, these models encompass a range of key components of aquatic ecosystems, including a closed nutrient cycle, and phytoplankton and zooplankton dynamics. In the original model applications for the Danish lakes (Table 1), water col- umn temperature (and vertical mixing in case of the deep lake model application) was determined using a hydrodynamic model driven by observed climate forcing data for air temperature $\left({ }^{\circ} \mathrm{C}\right)$, wind speed $\left(\mathrm{m} \mathrm{s}^{-1}\right)$, shortwave radiation $\left(\mathrm{W} \mathrm{m}^{-2}\right)$, relative humidity $(\%)$, and cloud cover (\%). In this study, we adapted the climate forcing data of the original model applications to reflect that of the baseline and future scenario periods (Table 2) based on changes to the air temperature input to the models, whereas other meteorological variables remained the same as in the original model application. Thus, the yearly time series (represented by the median, 10th and 90th percentiles) of the climate model simulated daily air temperatures for the baseline and future scenarios were looped for the entire duration of the lake model applications, thereby allowing each application to retain its individual time series length, and consequently also the natural year to year variations in hydrology and external nutrient loads. By contrast, air temperatures had the same seasonality from year to year for each individual percentile. For the scenarios where future climates were combined with changed future nutrient loadings (estimated by the SWAT simulations), the future nutrient load was implemented by monthly change factors for phosphorus and nitrogen loads, respectively (allowing increasing loads in some months and decreasing in others, depending on the estimates of the eco-hydrological model simulations). When extracting the scenario results, the first year of simulation was discarded for each lake in all scenarios to reduce the effects of water temperature and biogeochemical state variable initializations (which were not changed between scenarios) on simulated outcomes. To enable scenario comparisons between lakes, we derived a yearly time series from daily data for each individual model application, representing the average of key state variables across the entire duration of the individual model applications, TP, TN, total chlorophyll a $(\mathrm{chl} a)$, the contribution of cyanobacteria biomass to total phytoplankton biomass (\%), and the zooplankton: phytoplankton biomass ratio.

\subsection{Empirical relations}

A series of empirical regressions between lake water quality attributes (e.g. biological indicators), water temperature, hydraulic load (inferred by retention time) and nutrient load were established to enable extrapolation to the future scenarios. To calculate the annual mean lake $\mathrm{TP}$ concentration $\left(\mathrm{TP}_{\text {lake }}\right)$ from the 
discharge-weighted annual mean inlet TP concentration $\left(\mathrm{TP}_{\text {in }}\right)$, we used the simple empirical Vollenweider model (OECD 1982) model:

$$
\mathrm{TP}_{\text {lake }}=\mathrm{TP}_{\text {in }}(1+\sqrt{ } \mathrm{TW})^{-1}
$$

where TW is the hydraulic retention time (in yr) in the lake. This model has given reasonably good results for Danish lakes (Jeppesen et al. 1991). We also used established relationships (Jeppesen et al. 1997) between annual means of $\mathrm{TP}_{\text {lake }}$ and lake mean depth $(Z, \mathrm{~m})$ and $\mathrm{chl}$ a $\left(\mu \mathrm{g} \mathrm{l}^{-1}\right)$ in the surface water, as well as water transparency (Secchi depth, m) from a dataset based on Danish lakes ( $\mathrm{TP}_{\text {lake }}$ range: $0.017-1.91 \mathrm{mg} \mathrm{P}^{-1}$, mean depth range: $0.7-16.5 \mathrm{~m}$ ):

$\operatorname{chl} a=\exp \left[5.78+0.85 \log \left(\mathrm{TP}_{\text {lake }}\right)-0.26 \log (\mathrm{Z})\right]$

Secchi depth $=$

$\exp \left[-1.23+0.45 \log \left(\mathrm{TP}_{\text {lake }}\right)+0.42 \log (\mathrm{Z})\right]$

with $\mathrm{R}^{2}=0.72, \mathrm{n}=60$ for Eq. (2) and $\mathrm{R}^{2}=0.75, \mathrm{n}=59$ for Eq. (3). We further developed new empirical regression models for August TP concentrations, cyanobacteria biomass and the size of cladocerans (a zooplankton-based indicator of fish predation, Jeppesen et al. 2010) in the present study, based on a general linear modelling (GLM) approach using forward selection of variables (input variables included $\mathrm{TP}_{\text {lake, }} Z$, and lake temperature). Using these regression models, we analyzed the effects of changes to temperature and nutrient load.

\section{RESULTS}

\subsection{Future nutrient exports}

The SWAT-simulated response of catchment hydrology and nutrient exports to the future change in mean air temperature and precipitation showed marked seasonality. The flow-weighted monthly discharge rates averaged across 11 stations on Funen suggest that discharge may decrease in late summer to early autumn (September to October) and increase in the remaining months (Fig. 1). The discharge will increase most during the winter months, up to $86 \%$ in January, and decrease most in October $(8 \%)$. The changes in discharge patterns influence nutrient exports, which tend to decrease for a longer period ranging from July to October, while increasing in the remaining months. The changes in nutrient export dynamics are most dramatic for $\mathrm{TP}$, increasing up to $119 \%$ in January relative to the baseline, and decreasing $26 \%$ in August, while the corresponding figures for TN is a $41 \%$ increase and a $42 \%$ decrease,
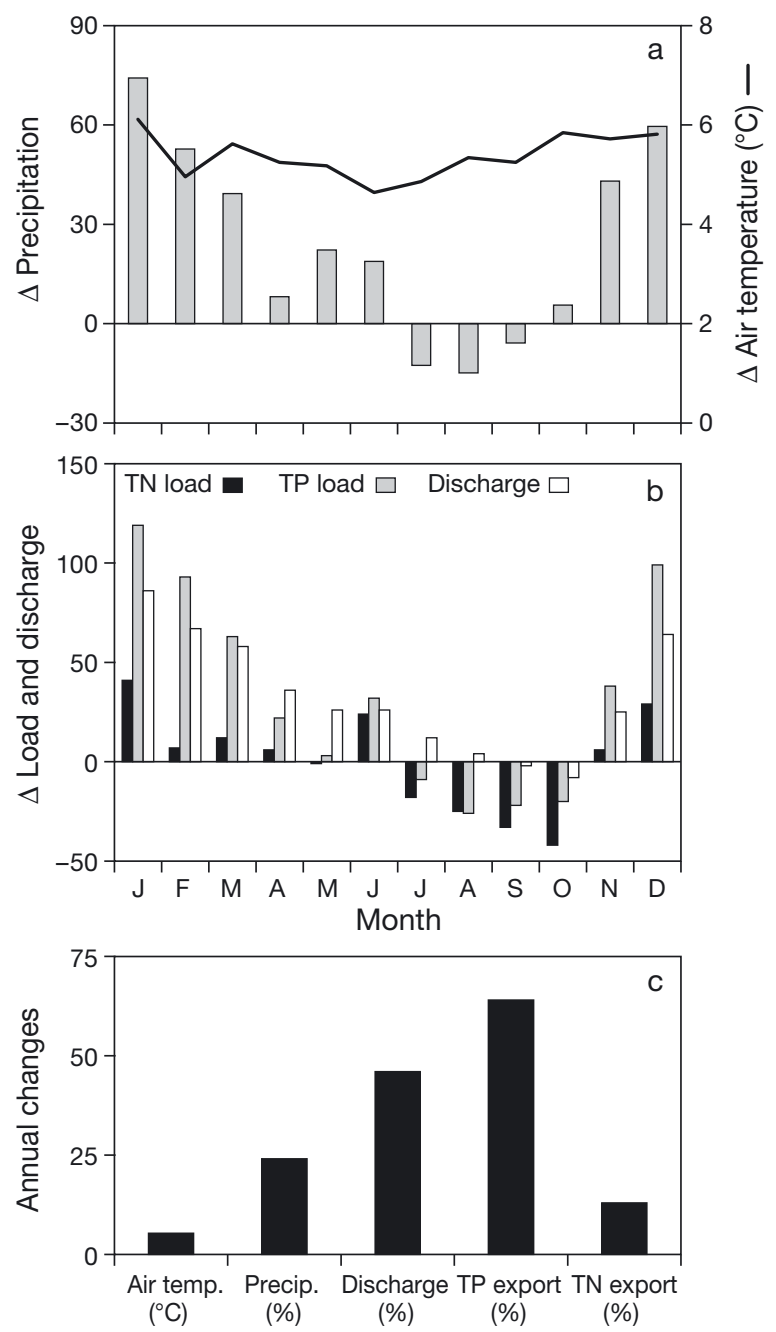

Fig. 1. (a) Monthly changes in precipitation and air temperature between the baseline and future climate periods, and (b) simulated monthly and (c) annual changes in discharge and nutrient exports (air temperature and precipitation also included in [c]). Variables are in \%, except temperature $\left({ }^{\circ} \mathrm{C}\right)$. TP: total phosphorus; TN: total nitrogen

respectively. On an annual basis, precipitation increases by $24 \%$, discharge rates by $46 \%$, TP exports by $64 \%$, and TN exports by $13 \%$ (Fig. 1), illustrating also that much of the increased precipitation falls during winter months with low actual evaporation (thus causing relative increases of runoff to change more than that of precipitation on an annual basis).

\subsection{Changes and variability in key properties of the aquatic ecosystems projected by the mechanistic models}

The natural year to year variability in temperature and phytoplankton biomass of the baseline scenario 
relative to the future scenario for the individual lakes reveals that the future will bring about changes that go beyond what we experience from the year to year variations of the present (Fig. 2). For example, the future minimum summer phytoplankton biomass in
Lake Arreskov is generally greater than the highest biomass achieved under the present climate (Fig. 2d). There is also a general tendency for the spring bloom to occur earlier in the future in all the lakes. Phytoplankton biomass generally increases in the future
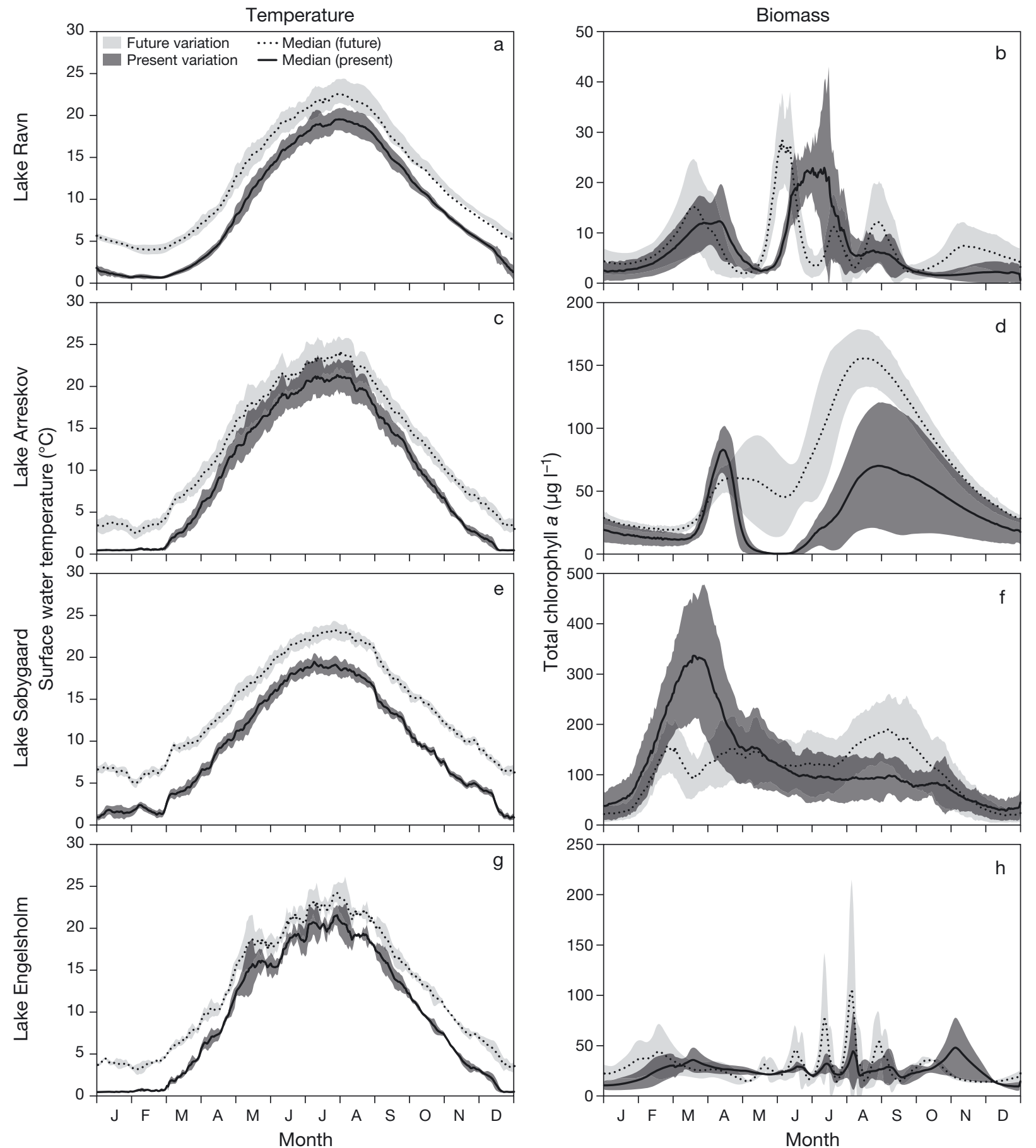

Fig. 2. Simulated surface water temperature and phytoplankton biomass (total chl a) for the 4 individual lakes for the baseline (SC1) and the future period with both increased air temperature and changed nutrient load (SC7). Variation bands are derived from the SD of year to year variations in surface water temperature and phytoplankton biomass (e.g. for Lake Arreskov, represented by 21 yr of simulation). See Table 3 for details on all scenarios 
scenario, in particular in late summer months, inferring that cyanobacteria become more dominant.

To disentangle the causes of the diversity in the simulated responses to climate change of the 4 case studies, we took a closer look at the simulated time
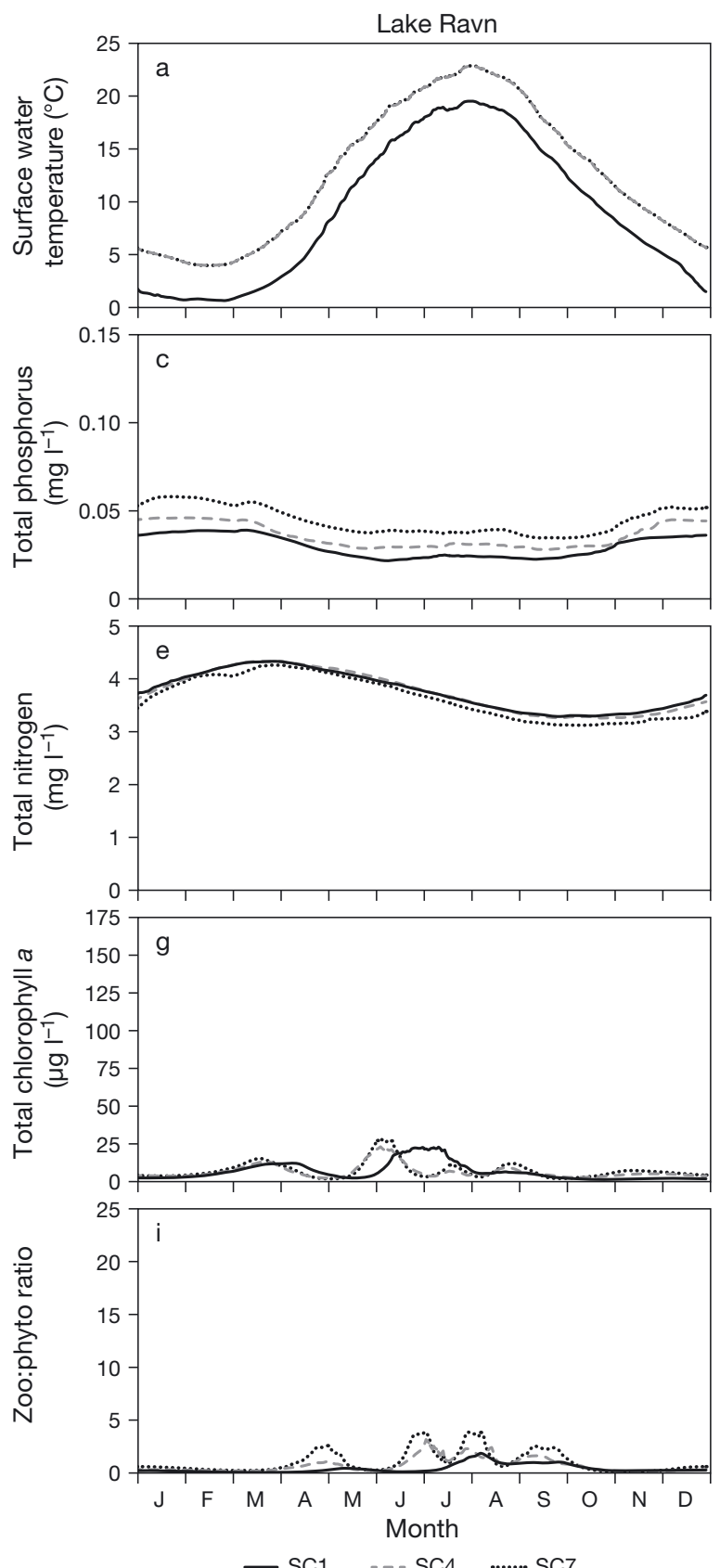

Fig. 3. Example of simulated outcomes of key water quality indicators (data extracted from surface) represented by a deep lake (Lake Ravn, left column) and a shallow lake (Lake Arreskov, right column) in response to baseline conditions (SC1) and changes in air temperature alone (SC4) and air temperature + nutrient loads combined (SC7) series of key water quality attributes for Lake Ravn, representing a mesotrophic deep lake, and Lake Arreskov, representing a eutrophic shallow lake (Fig. 3). Deep Lake Ravn generally exhibited surface water temperatures $1^{\circ}$ to $1.5^{\circ} \mathrm{C}$ below those simu-
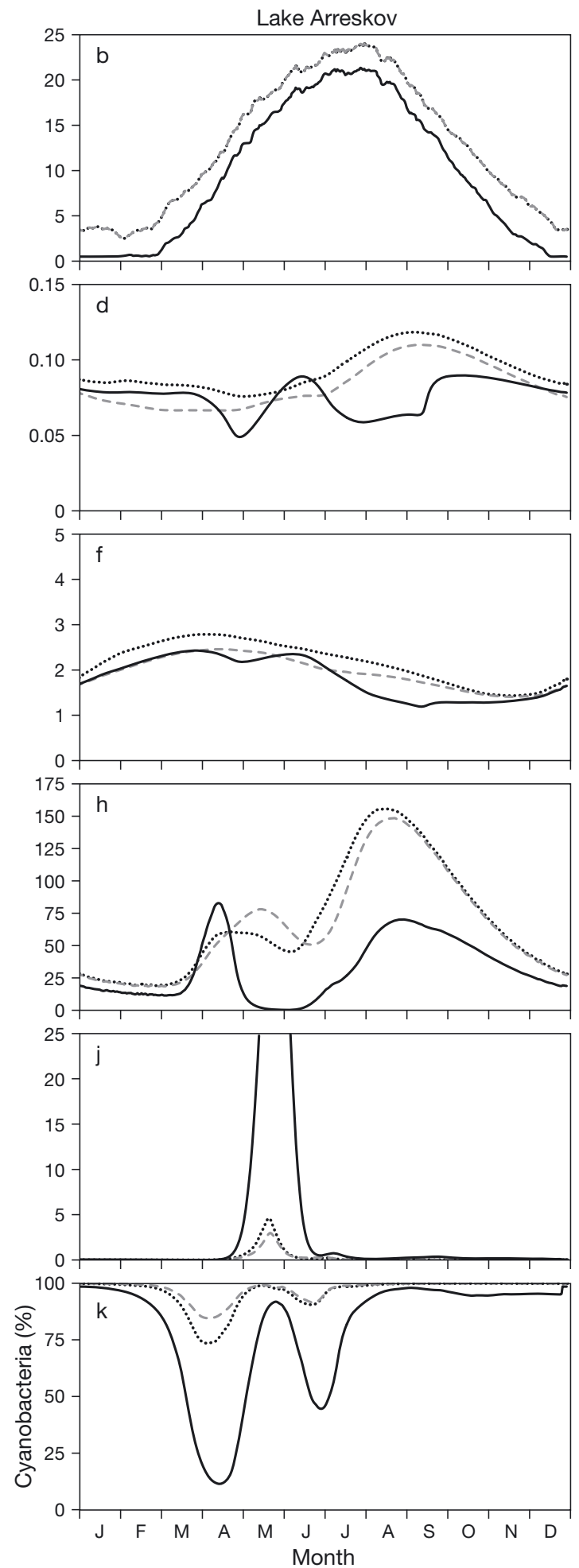
lated for Lake Arreskov for both the baseline and the future scenarios. The responses to climate change and increased nutrient loads appeared to be more uniformly distributed for Lake Ravn throughout the year, in particular for lake nutrient concentrations, while the changes simulated for Lake Arreskov were considerably higher in the summer months, likely reflecting internal phosphorus loading in summer, which is typical for this lake (Nielsen et al. 2014) and other shallow eutrophic temperate lakes (Søndergaard et al. 2013). The seasonality of phytoplankton biomass in Lake Ravn generally shows an earlier onset of the summer peak in biomass in the future scenario, reflecting earlier onset of stratification, while there were no apparent changes in the timing of the summer peak in Lake Arreskov, which, how-
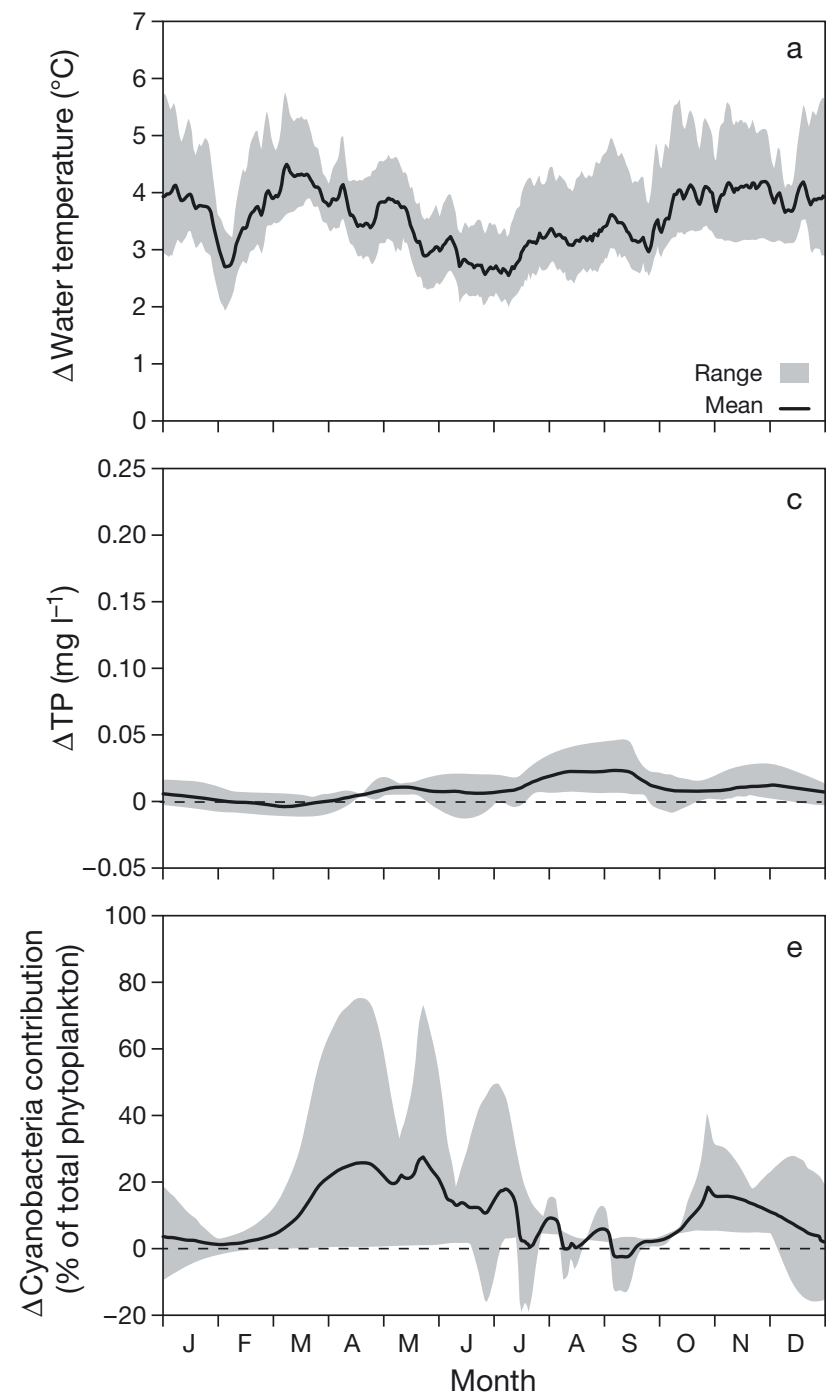

ever, was markedly higher relative to the baseline level. The occurrence of the clear-water phase between spring and summer blooms was reduced in the future scenarios for Lake Arreskov, and the simulated cyanobacteria biomass suggests that blooms may become a dominant feature of the phytoplankton community during spring, while diatoms dominate in spring in the baseline scenario.

When looking at the responses, and specifically the absolute changes between the median baseline and future scenarios, the effects of increased air temperature alone (SC4) suggest that key water quality attributes including $\mathrm{TP}, \mathrm{TN}$, and chl a concentrations may increase during summer, while remaining close to, or below, baseline levels in the other seasons (Fig. 4). The simulations also suggest that cyano-
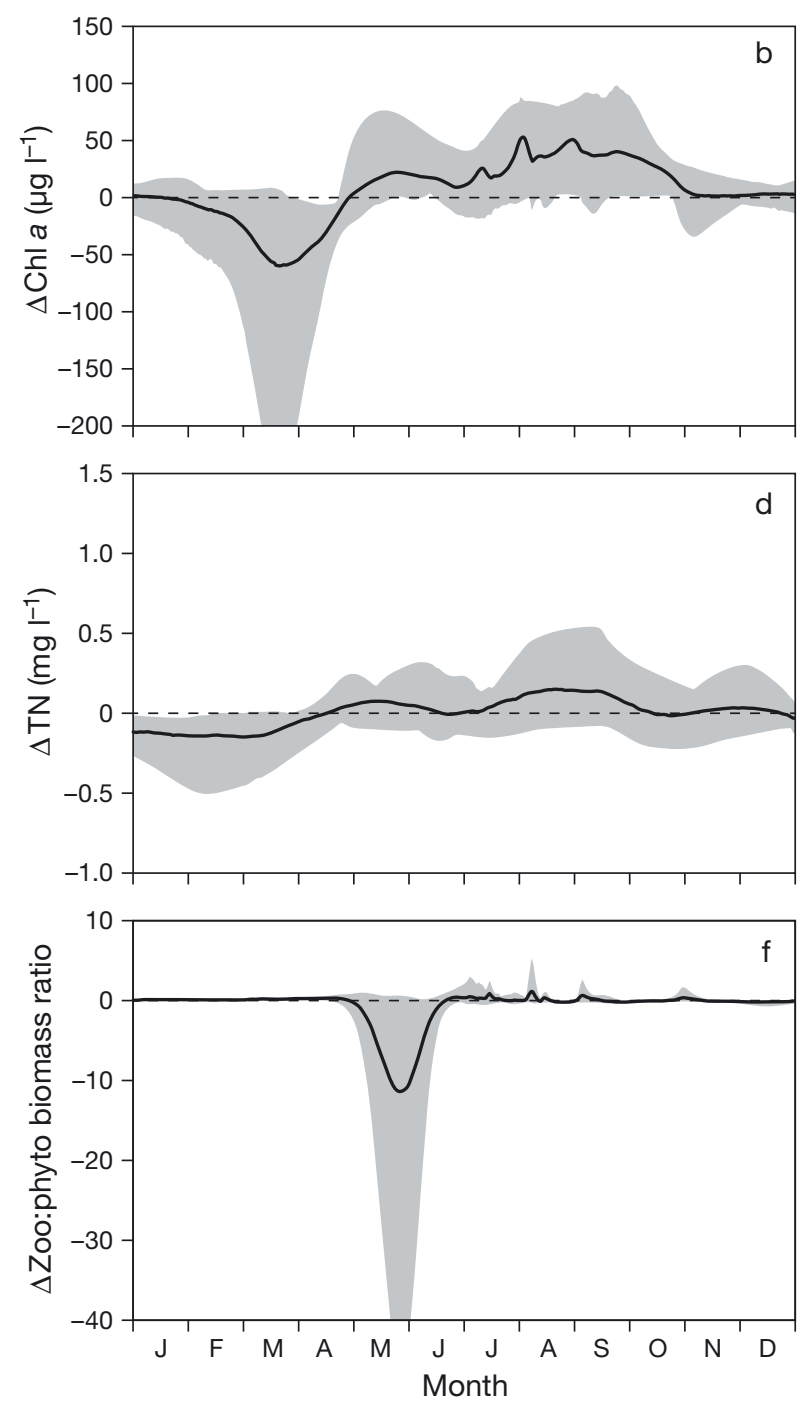

Fig. 4. Simulated seasonal changes in key water quality indicators across the 4 lakes (data extracted from surface) represented by mechanistic ecosystem models in response to median changes in air temperature (SC4 minus SC1). Gray band: range in simulated changes; black line: mean change across all 4 case study lakes; TP: total phosphorus; TN: total nitrogen 
bacteria will become a more dominant feature of the phytoplankton community from spring, while there is no marked change during the summer months where they are already a dominant feature of the phytoplankton community in the baseline scenario (i.e. for the case studies that included cyanobacteria, including lakes Arreskov, Søbygaard, and Engelsholm). There are, however, also considerable discrepancies between the simulated responses for the 4 different lakes, as represented by the wide band of model outcomes around the mean response for cyanobacteria (Fig. 4). When comparing simulations of the median future scenario with that of the 90th percentile of air temperatures in the baseline scenario (Table 3), it is apparent that the future scenario is different from even the warmest days of the present time (i.e. the baseline scenario). For example, the simulated water temperature of the median year of the future is $\sim 1.5^{\circ} \mathrm{C}$ warmer than the 90th percentile of the baseline scenario on both an annual basis and during the summer months. Further, when comparing simulated water temperatures, the 10th percentile of the future scenario is within the range of the 90th percentile of the baseline scenario.

As future air temperatures are combined with the estimates of future nutrients loads, the simulated outcomes change considerably (Fig. 5), and at the same time the discrepancy between simulated responses of the 4 case studies increase (comparing the gray bands in Fig. 5 with those in Fig. 4). For example, while TP only increased in the summer months in the scenarios where only air temperature was changed, it increased throughout the year in scenarios involving changes in both temperature and nutrient loads. In the temperature+nutrient load change scenario, lake TN concentrations increased in the winter months (Fig. 5d) but were generally below baseline levels in winter in the temperature-only scenario (Fig. 4d). For the remaining water quality attributes, the patterns in simulated responses were similar between scenarios where only air temperatures were changed to those where both air temperature and nutrient loads were changed.

\subsection{Changes in the key properties of the aquatic ecosystems projected by the empirical relations}

Based on data from Danish lakes, we established a relationship between August $\mathrm{TP}_{\text {lake }}\left(\mathrm{TP}_{\text {lake_aug }}\right)$ and annual mean $\mathrm{TP}_{\text {lake }}$ and $Z$ :

$\mathrm{TP}_{\text {lake_aug }}=\exp [0.745 \pm 0.033+(1.166 \pm 0.014) \log$

$\left.\left(\mathrm{TP}_{\text {lake }}\right)-(0.175 \pm 0.014) \log (Z)\right]$ where $\mathrm{R}^{2}=0.85, \mathrm{n}=1270$ (number of lake years and not number of individual lakes); the range of variables being: $0.006-1.96 \mathrm{mg} \mathrm{l}^{-1}$ for $\mathrm{TP}_{\text {lake_aug }}$ $0.2-16.5 \mathrm{~m}$ for $Z$.

We further developed a relationship between biomass of cyanobacteria $\left(\mathrm{mm}^{3} \mathrm{l}^{-1}\right)$ in August $\left(\mathrm{TP}_{\text {lake_aug }}\right)$, August mean water temperature $\left(\mathrm{Temp}_{\mathrm{W} \_ \text {aug, }}{ }^{\circ} \mathrm{C}\right)$, and $Z$ :

Cyano $_{\text {aug }}=\exp [-6.75 \pm 0.26+(1.120 \pm 0.087) \log$

$\left(\mathrm{TP}_{\text {lake_aug }}\right)+(2.84 \pm 0.87) \log \left(\mathrm{Temp} \mathrm{W}_{\mathrm{W} \_ \text {aug }}\right)+$

$(0.319 \pm 0.12) \log (Z)]$

where $\mathrm{R}^{2}=0.21, \mathrm{n}=1029$; the range of input variables being: $0.006-4.10 \mathrm{mg} \mathrm{l}^{-1}$ for $\mathrm{TP}_{\text {lake_aug }} 0.2-15 \mathrm{~m}$ for $Z_{\text {, and }} 11.1-26.1^{\circ} \mathrm{C}$ for Temp $\mathrm{W}_{\text {_aug }}$.

Finally, we derived a regression between the size (inferred by biomass) of cladocerans (ClaSize ${ }_{\text {augi }} \mu \mathrm{gg}$ ind. ${ }^{-1}$ ) and $\mathrm{TP}_{\text {lake_aug, }}$ Temp $\mathrm{P}_{\mathrm{W}_{\text {aug }}}$ and $Z$ :

$\mathrm{ClaSize}_{\text {aug }}=\exp \left[-(0.02 \pm 0.01) \log \left(\mathrm{TP}_{\text {lake_aug }}\right)-\right.$ $\left.(0.76 \pm 0.22) \log \left(T e m p_{\mathrm{W}_{\text {_aug }}}\right)+(0.42 \pm 0.04) \log (Z)\right]$

where $R^{2}=0.16, n=953$; the range of input variables being: $0.006-2.45 \mathrm{mg} \mathrm{l}^{-1}$ for $\mathrm{TP}_{\text {lake_aug }} 0.3-15 \mathrm{~m}$ for $Z$, and $11.1-26.6^{\circ} \mathrm{C}$ for $\mathrm{Temp}_{\mathrm{W} \_ \text {aug }}$.

When forced with the future nutrient load estimates (TP load increases by $64 \%$ ), the empirical relationships suggest an increase in annual mean $\mathrm{TP}_{\text {lake }}$ ranging from $43 \%$ in lakes with a retention time of $0.01 \mathrm{yr}$ to $\sim 28 \%$ with a retention time of $20 \mathrm{yr}$, leading to a Secchi depth decline to $~ 89$ and $83 \%$ of the baseline levels, respectively (Fig. 6). The concentrations of annual mean chl $a$ and Secchi depth in lakes with different $\mathrm{TP}_{\text {lake }}$ concentrations and different depths are given in Fig. 7 for the baseline annual mean TP loading and temperature and for the predicted future loading, showing the highest $\mathrm{chl} a$ and lowest Secchi depth in shallow lakes. The cyanobacteria biomass in August is predicted to increase substantially depending on the $\mathrm{TP}_{\text {lake }}$ concentration, depth, temperature and retention time, and the size of cladocerans is projected to decrease. In Fig. 8 this is illustrated for 2 examples: (1) a shallow lake with a mean depth of $3 \mathrm{~m}$ and a $1 \mathrm{yr}$ retention time, and (2) a deep lake with a mean depth of $15 \mathrm{~m}$ and a $10 \mathrm{yr}$ retention time. The differences between the 3 baseline scenarios (SC1-3) and the future scenario with increased temperatures+nutrient loads (SC7-9) are overall larger for the shallow lake type, and the difference increases with increasing $\mathrm{TP}_{\text {lake. }}$. The maximum level is also higher for the shallow lake, reflecting the effect of depth on both $\mathrm{TP}_{\text {lake_aug }}$ and on cyanobacteria biomass (see equations in 'Methods' section). The body size of cladocerans in August declines with increas- 
Table 3. Annual and summer (Jun-Aug) averages of modeled state variables for all 4 mechanistic models and all scenarios (SC1-9). TP: total phosphorus ( $\mathrm{mg} \mathrm{l}^{-1}$ ); TN: total nitrogen ( $\mathrm{mg} \mathrm{l}^{-1}$ ); Zoo(Phyto): zoo-(phyto-)plankton; Cyano: cyanobacteria (\%). Water temperature is in ${ }^{\circ} \mathrm{C} ; \mathrm{chl} a$ is in $\mathrm{mg} \mathrm{l}^{-1}$

\begin{tabular}{|c|c|c|c|c|c|c|c|c|c|}
\hline \multirow[t]{2}{*}{ Scenario } & \multirow[b]{2}{*}{ State variable } & \multicolumn{2}{|c|}{ Lake Ravn } & \multicolumn{2}{|c|}{ Lake Arreskov } & \multicolumn{2}{|c|}{ Lake Engelsholm } & \multicolumn{2}{|c|}{ Lake Søbygaard } \\
\hline & & Annual & Summer & Annual & Summer & Annual & Summer & Annual & Summer \\
\hline \multirow[t]{6}{*}{ SC1 } & Water temperature & 9.07 & 17.81 & 9.73 & 19.84 & 9.60 & 19.08 & 9.54 & 18.02 \\
\hline & $\mathrm{TP}$ & 0.03 & 0.02 & 0.08 & 0.07 & 0.05 & 0.05 & 0.29 & 0.44 \\
\hline & $\mathrm{TN}$ & 3.77 & 3.68 & 1.81 & 1.84 & 1.21 & 0.69 & 2.37 & 1.69 \\
\hline & $\mathrm{Chl} \mathrm{a}$ & 6.60 & 13.00 & 31.52 & 30.07 & 24.94 & 26.17 & 120.44 & 97.36 \\
\hline & Zoo:Phyto & 0.41 & 0.68 & 3.50 & 4.66 & 0.38 & 0.83 & 0.27 & 0.47 \\
\hline & Cyano & & & 79.89 & 77.61 & 34.67 & 72.25 & 4.50 & 7.27 \\
\hline \multirow[t]{6}{*}{ SC2 } & Water temperature & 7.75 & 16.77 & 8.45 & 18.92 & 8.26 & 18.14 & 7.98 & 16.62 \\
\hline & $\mathrm{TP}$ & 0.03 & 0.02 & 0.07 & 0.05 & 0.04 & 0.05 & 0.29 & 0.43 \\
\hline & $\mathrm{TN}$ & 3.84 & 3.73 & 1.70 & 1.65 & 1.29 & 0.98 & 2.40 & 1.73 \\
\hline & Chl a & 6.46 & 12.74 & 25.15 & 19.29 & 24.68 & 25.66 & 131.81 & 98.93 \\
\hline & Zoo:Phyto & 0.38 & 0.59 & 8.85 & 22.22 & 0.43 & 0.81 & 0.27 & 0.50 \\
\hline & Cyano & & & 64.41 & 74.07 & 29.21 & 68.86 & 2.82 & 5.40 \\
\hline \multirow[t]{6}{*}{ SC3 } & Water temperature & 10.97 & 19.55 & 11.30 & 21.11 & 11.23 & 20.38 & 11.89 & 20.01 \\
\hline & $\mathrm{TP}$ & 0.03 & 0.03 & 0.08 & 0.09 & 0.05 & 0.05 & 0.30 & 0.46 \\
\hline & $\mathrm{TN}$ & 3.77 & 3.69 & 2.04 & 2.23 & 1.15 & 0.68 & 2.30 & 1.64 \\
\hline & Chl a & 6.60 & 11.54 & 55.34 & 77.99 & 24.71 & 29.61 & 108.43 & 109.11 \\
\hline & Zoo:Phyto & 0.53 & 1.04 & 0.96 & 0.87 & 0.43 & 0.91 & 0.26 & 0.38 \\
\hline & Cyano & & & 91.06 & 89.13 & 40.72 & 77.13 & 7.21 & 9.90 \\
\hline \multirow[t]{6}{*}{$\mathrm{SC4}$} & Water temperature & 12.55 & 20.96 & 12.84 & 22.29 & 12.73 & 21.58 & 14.02 & 21.91 \\
\hline & $\mathrm{TP}$ & 0.04 & 0.03 & 0.08 & 0.09 & 0.06 & 0.07 & 0.30 & 0.45 \\
\hline & $\mathrm{TN}$ & 3.75 & 3.69 & 1.94 & 2.00 & 1.21 & 0.90 & 2.26 & 1.57 \\
\hline & Chl a & 6.48 & 9.26 & 65.97 & 94.94 & 27.20 & 37.97 & 108.74 & 131.09 \\
\hline & Zoo:Phyto & 0.73 & 1.43 & 0.20 & 0.19 & 0.63 & 1.16 & 0.24 & 0.30 \\
\hline & Cyano & & & 97.55 & 97.35 & 40.87 & 76.68 & 10.66 & 10.23 \\
\hline \multirow[t]{6}{*}{ SC5 } & Water temperature & 10.79 & 19.90 & 11.17 & 21.50 & 11.07 & 20.77 & 11.70 & 20.65 \\
\hline & $\mathrm{TP}$ & 0.03 & 0.03 & 0.08 & 0.09 & 0.05 & 0.05 & 0.30 & 0.47 \\
\hline & $\mathrm{TN}$ & 3.78 & 3.69 & 2.04 & 2.25 & 1.20 & 0.69 & 2.29 & 1.64 \\
\hline & Chl $a$ & 6.79 & 12.68 & 51.40 & 65.70 & 24.30 & 30.18 & 116.99 & 112.48 \\
\hline & Zoo:Phyto & 0.52 & 1.00 & 1.67 & 1.11 & 0.42 & 0.93 & 0.24 & 0.37 \\
\hline & Cyano & & & 87.61 & 81.05 & 40.43 & 76.38 & 7.15 & 10.16 \\
\hline \multirow[t]{6}{*}{ SC6 } & Water temperature & 14.06 & 22.50 & 14.30 & 23.55 & 14.15 & 22.89 & 16.14 & 23.98 \\
\hline & $\mathrm{TP}$ & 0.04 & 0.03 & 0.08 & 0.09 & 0.05 & 0.05 & 0.30 & 0.44 \\
\hline & $\mathrm{TN}$ & 3.79 & 3.73 & 1.86 & 1.88 & 1.07 & 0.65 & 2.23 & 1.52 \\
\hline & Chl a & 6.71 & 8.98 & 72.08 & 110.89 & 26.65 & 34.69 & 125.48 & 192.08 \\
\hline & Zoo:Phyto & 0.75 & 1.43 & 0.05 & 0.08 & 0.53 & 0.99 & 0.21 & 0.16 \\
\hline & Cyano & & & 99.44 & 99.88 & 42.71 & 79.15 & 12.20 & 7.65 \\
\hline \multirow[t]{6}{*}{ SC7 } & Water temperature & 12.56 & 20.99 & 12.84 & 22.29 & 12.73 & 21.58 & 14.02 & 21.91 \\
\hline & $\mathrm{TP}$ & 0.04 & 0.04 & 0.09 & 0.10 & 0.07 & 0.08 & 0.36 & 0.48 \\
\hline & $\mathrm{TN}$ & 3.64 & 3.57 & 2.17 & 2.29 & 1.15 & 0.79 & 2.39 & 1.53 \\
\hline & $\mathrm{Chl} \mathrm{a}$ & 7.35 & 10.59 & 68.29 & 105.76 & 28.09 & 37.17 & 108.15 & 134.67 \\
\hline & Zoo:Phyto & 1.05 & 1.88 & 0.27 & 0.18 & 0.62 & 1.26 & 0.24 & 0.28 \\
\hline & Cyano & & & 96.18 & 96.81 & 44.67 & 78.13 & 11.55 & 11.03 \\
\hline \multirow[t]{6}{*}{ SC8 } & Water temperature & 10.80 & 19.92 & 11.17 & 21.50 & 11.07 & 20.78 & 11.70 & 20.65 \\
\hline & $\mathrm{TP}$ & 0.04 & 0.04 & 0.10 & 0.11 & 0.06 & 0.06 & 0.36 & 0.50 \\
\hline & $\mathrm{TN}$ & 3.64 & 3.57 & 2.28 & 2.53 & 1.17 & 0.70 & 2.41 & 1.59 \\
\hline & Chl a & 7.15 & 10.80 & 53.30 & 65.82 & 26.56 & 32.60 & 116.48 & 114.68 \\
\hline & Zoo:Phyto & 0.85 & 1.61 & 2.04 & 1.24 & 0.58 & 1.11 & 0.23 & 0.36 \\
\hline & Cyano & & & 86.16 & 77.78 & 38.10 & 78.19 & 7.79 & 10.78 \\
\hline \multirow[t]{6}{*}{ SC9 } & Water temperature & 14.06 & 22.51 & 14.30 & 23.55 & 14.15 & 22.90 & 16.14 & 23.98 \\
\hline & $\mathrm{TP}$ & 0.05 & 0.04 & 0.09 & 0.10 & 0.06 & 0.06 & 0.36 & 0.47 \\
\hline & $\mathrm{TN}$ & 3.67 & 3.60 & 2.08 & 2.13 & 1.09 & 0.75 & 2.37 & 1.48 \\
\hline & Chl a & 7.56 & 10.33 & 75.32 & 119.77 & 28.49 & 39.87 & 118.07 & 181.01 \\
\hline & Zoo:Phyto & 1.09 & 2.01 & 0.06 & 0.07 & 0.73 & 1.20 & 0.21 & 0.18 \\
\hline & Cyano & & & 99.00 & 99.86 & 41.58 & 78.04 & 15.02 & 9.26 \\
\hline
\end{tabular}



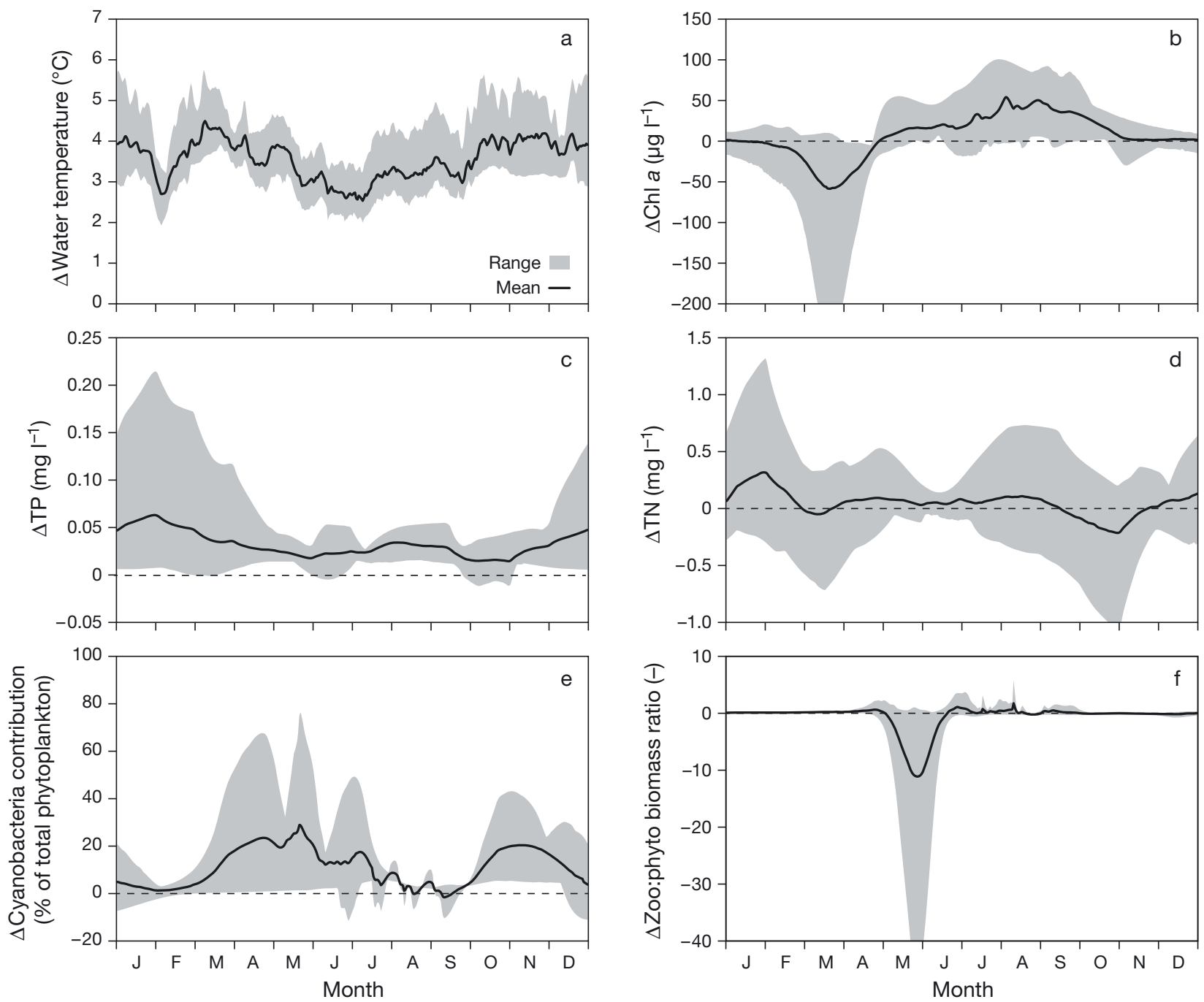

Fig. 5. Simulated seasonal changes in key water quality indicators across the 4 lakes (data extracted from surface) represented by mechanistic ecosystem models in response to changes in air temperature + changes in nutrient load (SC7 minus SC1). See Fig. 4 for definitions

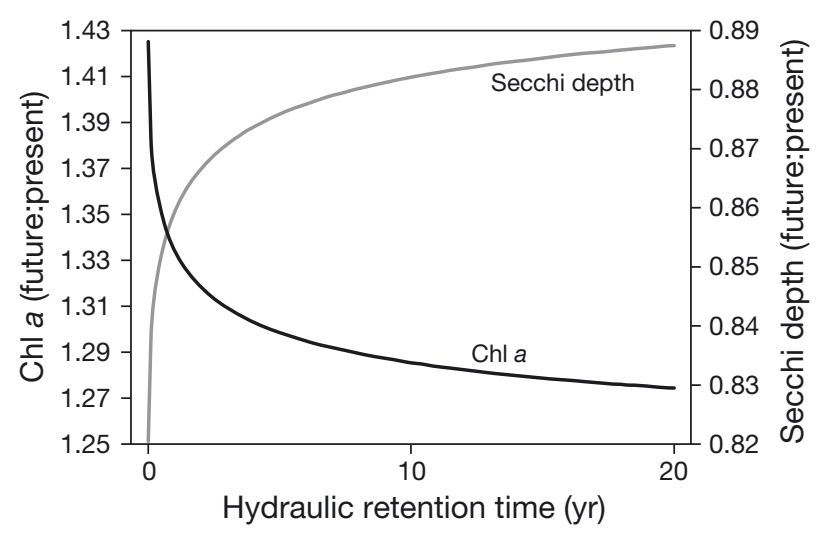

Fig. 6. Effect of increased loading and shorter retention time in the future scenario (data from Fig. 1) on the annual mean lake concentration of chl $a$ and Secchi depth in Danish lakes with contrasting water retention time. Effects are shown as ratios between future:present-day situation ing temperature, most markedly in the deep lakes, as the size is already small in the present-day situations (SC1-3) in shallow lakes (Fig. 8) due to expected high fish predation (Jeppesen et al. 2000). Also, the differences among SC1-3 and SC7-9, respectively, are larger in the deep lakes when evaluating the change in size of cladocerans.

\section{DISCUSSION}

\subsection{Projected effects of climate change vs. empirical evidence}

Both the mechanistic and empirical models projected considerably increased warming-induced eutrophication as well as increased nutrient loadings in 

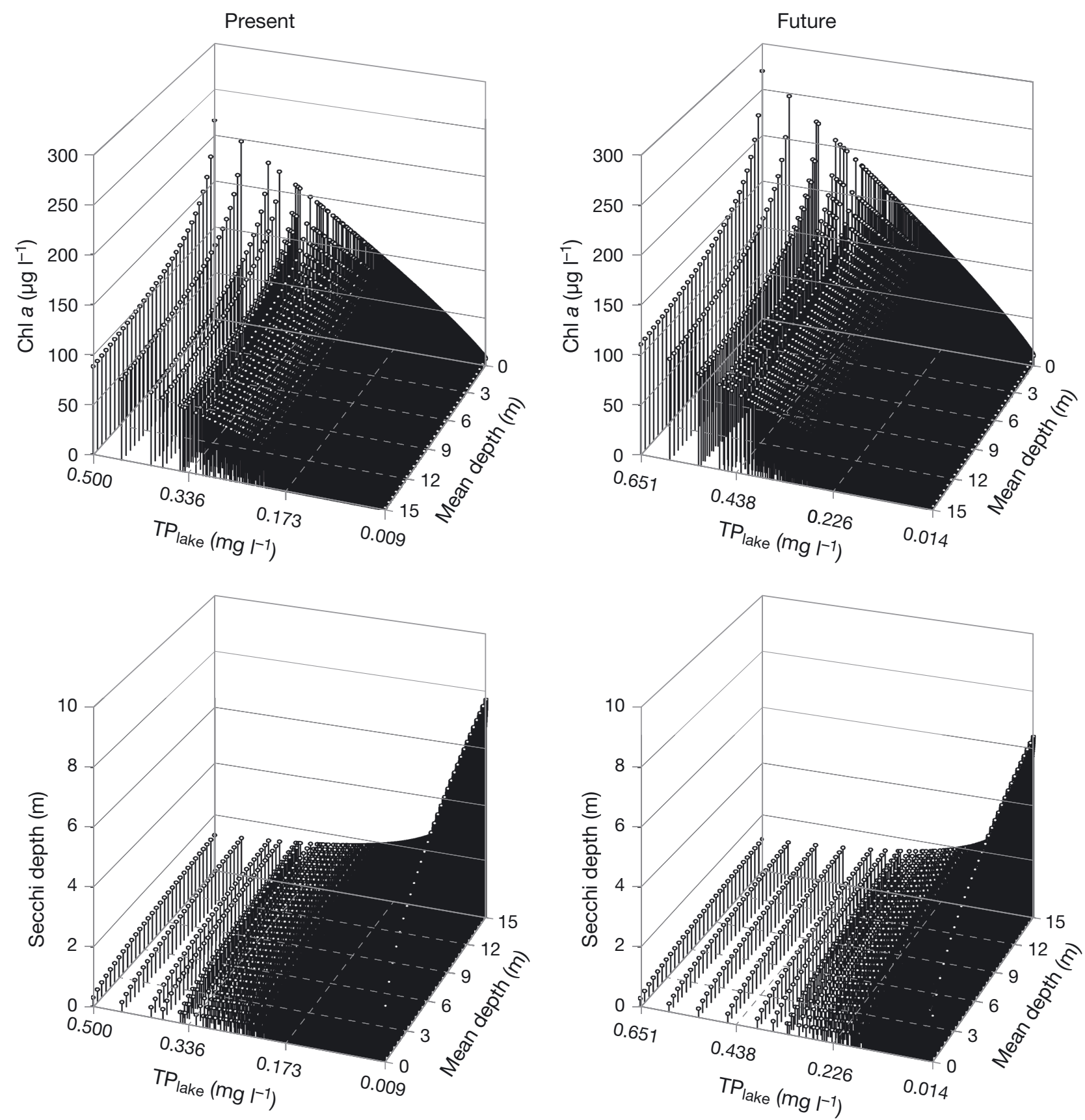

Fig. 7. Present-day (left) and predicted (right) concentration of annual mean chl $a$ and Secchi depth in lakes with contrasting total phosphorus concentrations $\left(\mathrm{TP}_{\text {lake}}\right.$ ) and depths. Note differing $\mathrm{TP}_{\text {lake }}$ axes, as the concentrations in the right panels reflect the higher future concentrations. Note also the reversed depth axes from the upper to the lower panels to enhance visibility of the data

the future for Danish lakes. While the additional nutrient load in the future scenario (SC7) had significant impact in the lakes' nutrient levels, minor effects were seen on biological variables relative to the effects of increased temperatures alone (SC4). This suggests that as the lakes get warmer, and nutrient cycling processes intensify, productivity may become decreasingly nutrient limited, and instead controlled increasingly by temperature and light availability. The total phytoplankton biomass is projected to increase the largest amount during the summer months, and the presence of potentially toxin-producing cyanobacteria is projected to be amplified and likely to become a dominant feature of the phytoplankton 


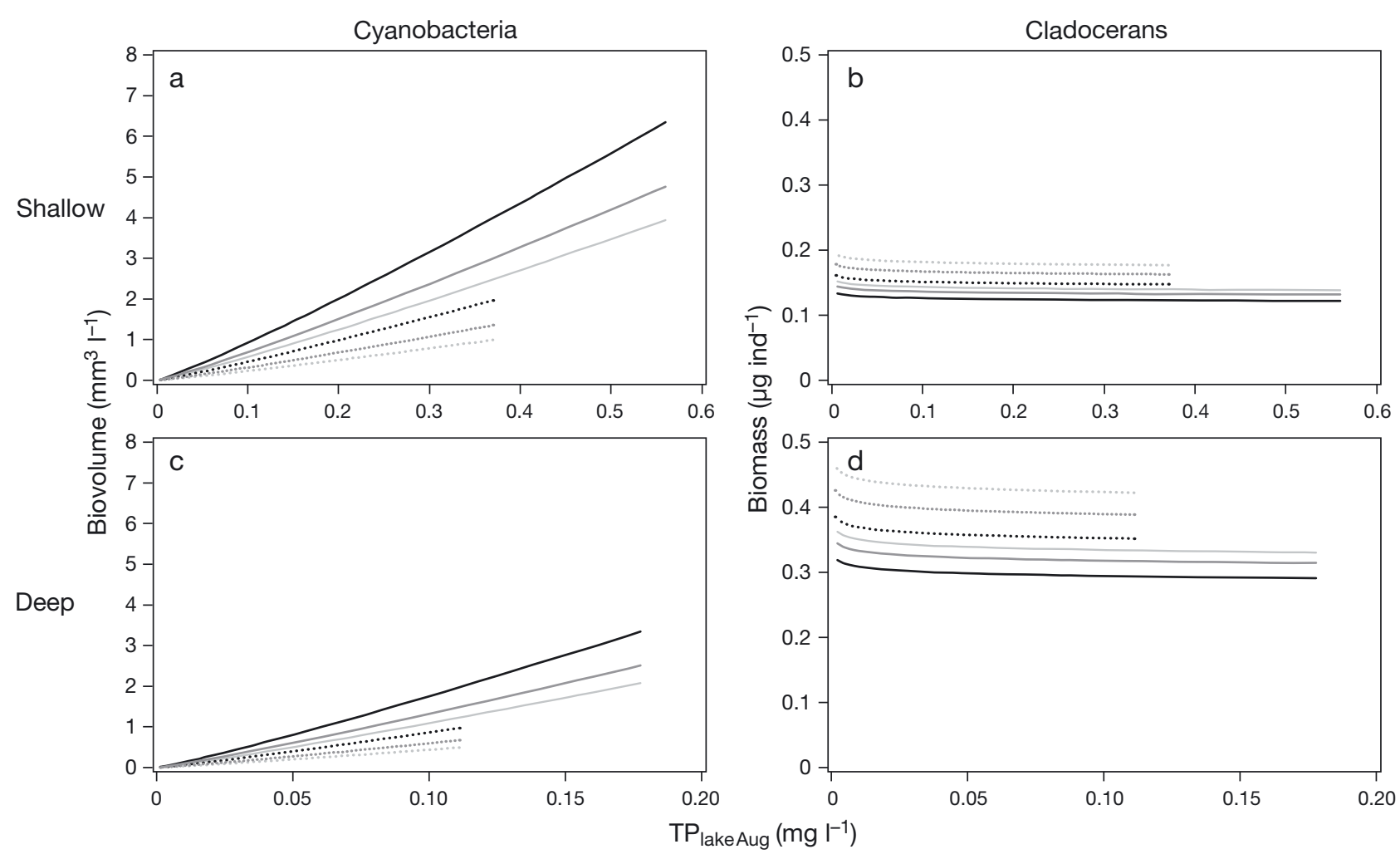

Fig. 8. Outcome of the empirical modelling of $(a, c)$ cyanobacteria biomass and $(b, d)$ average biomass of cladocerans $(\mu g$ dry wt ind. ${ }^{-1}$ ) in August in both $(\mathrm{a}, \mathrm{b})$ shallow and $(\mathrm{c}, \mathrm{d})$ deep lakes with mean depths of 3 and $15 \mathrm{~m}$ and 1 and $10 \mathrm{yr}$ retention times, respectively, run at contrasting lake water phosphorus concentrations $\left(\mathrm{TP}_{\text {lake }}\right)$. Dotted lines: present-day scenario (SC1-3); solid lines: future scenario (SC7-9). Increasing shade of gray: 10th percentile, median, and 90th percentile

community from spring. According to the model projections, this shift towards cyanobacteria dominance in spring is accompanied by a shift in the balance of the ecosystem, with a generally declining grazing pressure by zooplankton on phytoplankton; this is evidenced by the lower zooplankton to phytoplankton biomass ratio, particularly during spring. Such shifts in ecosystem structure and balance have also been reported in literature based on empirical observations. For example, Jeppesen et al. (2010) showed that a warming-triggered shift in fish community structure and abundance is to be expected, potentially leading to dominance by small-sized fish, lower zooplankton grazing, stronger cyanobacterial dominance, and higher internal nutrient loading. Moss et al. (2011) suggested that the future warming and increased nutrient loads will work synergistically and amplify such eutrophication effects, and that lake ecosystems therefore face 'allied attacks'. Monitoring data from Danish lakes collected in late summer (15 August to 15 September) from 1989 to 2006 also revealed a significant increase in the proportion of small perch Perca fluviatilis and bream Abramis brama with increasing temperature (Jeppesen et al.
2010) despite an overall major reduction in nutrient levels (reduction of the external nutrient loading), the latter of which (seen in isolation) should have resulted in a lower proportion of small fish (Jeppesen et al. 2000). Moreover, a long-term study conducted in shallow Lake Søbygaard showed a major decline in the average size of key fish species (Jeppesen et al. 2012). The decline coincided well with the change in average summer air temperature, indicating that the changes might reflect the enhanced ambient temperature. In accordance with this, the empirical data analyses (Fig. 8) predict a future decrease in the size of cladocerans, which concurs with higher fish predation, as the fish generally have a preference for larger-bodied individuals (Gliwicz 2003). Fish abundance and size may also be influenced by lower ice cover in winter, allowing higher survival of small fish with cascading effects on the food web and, with this, stronger symptoms of eutrophication (Jackson et al. 2007, Balayla et al. 2010, Ruuhijärvi et al. 2010). Cross-latitude gradient studies of shallow lakes have shown that the ratio of fish biomass (expressed as catches per net in multi-mesh sized gillnets) to zooplankton biomass increased from northern to south- 
ern Europe, while the zooplankton:phytoplankton biomass ratio decreased, both substantially (Gyllström et al. 2005). Thus, the projections by the models used in the present study are generally supported by empirical evidence. However, the strong changes in the food web structure observed in the empirical data are not yet well-implemented in the predictive models, emphasizing that the projected eutrophication effects of climate warming by the models may be conservative (i.e. the effects may be greater than our projections).

Both the mechanistic and empirical models predict an overall higher concentration of TP in the lakes, and thus higher concentrations in the lake outlets. Combined with higher discharge rates, the nutrient loading eventually reaching the coastal area will also increase quite substantially and contribute to the deterioration of the ecological state of these environments.

\subsection{Pitfalls and uncertainties of our approaches}

The 2 approaches used in this study to project the future state of lake ecosystems, based on mechanistic and empirical lake models, respectively, are associated with uncertainty. Projections by mechanistic models are only valid as long as the forcing data (e.g. temperature) are within the range for which the process descriptions in the models are still valid (e.g. the influence of temperature on the growth rates of phytoplankton). Empirical models are only applicable within the range of forcing data for which they have originally been developed (typically a more narrow range relative to the validity range of mechanistic models), and great care must be taken when extrapolating beyond this range. Based on hydrological modelling studies, Refsgaard et al. (2014) also demonstrated that model performance continues to deteriorate when the models are driven by forcing data differing increasingly from the forcing data for which the models had originally been applied and calibrated. Given the rather extreme warming scenarios simulated in this study, both the mechanistic and empirical models are applied at the periphery of their validity (and in reality extrapolated beyond the range of validity in the case of the empirical models); thus our projections should be treated with caution.

In our study, the future climate is based only on a single $\mathrm{CO}_{2}$-emission scenario in combination with one GCM-RCM model, and is downscaled with one bias-correction approach. Recent studies have highlighted the need for using an ensemble of climate models (Déqué et al. 2007) as the climate change signal has been shown to differ substantially between climate models (Seaby et al. 2013). Therefore, care should also be taken when analyzing impacts from only one GCM-RCM combination, and a larger ensemble of climate models would help to evaluate the findings of the present study. Karlsson et al. (2015) compared the ECEARTH-HIRHAM model projections for RCP4.5 to 4 other models from the ENSEMBLES project based on the A1B scenario. They found that the ECEARTH-HIRHAM for RCP4.5 had a temperature signal comparable to the median of the 4 ENSEMBLES A1B projections. As RCP4.5 is a scenario with generally less changes in forcing relative to A1B (Collins et al. 2013), with the median of the $\mathrm{A} 1 \mathrm{~B}$ projections corresponding to the high end of the RCP 4.5 range, it appears that the ECEARTHHIRHAM may provide projections that are warmer and show higher temperatures than the average of an ensemble of models. However, this is not critical for the conclusions of our study, since we focus on the impacts occurring when, at some future point in time, warming has increased by $6^{\circ} \mathrm{C}$.

The results of comparing scenarios SC4 and SC7 clearly show the large changes in nutrient exports, and the subsequent consequences for the concentrations of TP and TN, in the Danish lakes (Table 3). In our scenarios we assumed no major adaptation to climate change in the agricultural practices that contribute a considerable portion of nutrient exports to waterways. In reality, farmers would shift to growing crop species and varieties with higher productivity under climate change, which in northern Europe in particular means shifting from the currently grown cereals to grain maize (Elsgaard et al. 2012) and cereals with a longer growth duration (Olesen et al. 2012). Enhancing crop growth may reduce some of the large projected losses of nutrients (e.g. Patil et al. 2012). However, such effects of adaptation are likely to be small, as are those of other options to mitigate nutrient losses from agriculture, for instance growing catch crops (Doltra et al. 2014), since the major effects leading to enhanced loss of $\mathrm{N}$ and $\mathrm{P}$ under climate change are related to the land use practices of growing cereal crops. The major uncertainties associated with the estimated enhanced loading of $\mathrm{N}$ and $\mathrm{P}$ to the lakes are therefore associated with future land use practices, in particular whether the current high proportion of arable land in Denmark is maintained or whether some of that land use is converted to perennial cropping systems such as grassland for producing biomass for feed, energy, and other purposes (Smith \& Olesen 2010). 


\subsection{Ways forward for research into climate change effects on lake ecosystems}

There are many approaches available to examine the influence of climate forcing on ecosystem dynamics (Jeppesen et al. 2014). These all have their individual strengths and weaknesses, including "space-for-time substitution" (a challenge to separate climate effects from other anthropogenic, natural, and biogeographical effects); time-series and monitoring (a challenge to make realistic projections of the long-term changes related to ecosystem structures that may not be present under current climate conditions and also, for example, evolution and invasions); experiments (a challenge to undertake experiments at a realistic scale and sufficiently long-term duration); paleoecology (a challenge to disentangle the climate effect signals from eutrophication and other stressors); and modelling (a challenge to make models flexible and able to accurately reflect the real world ecosystems and their functions). As has already been seen for weather forecasts and global circulation models, an ensemble approach using different models (or different data series to drive a model) may also provide more robust projections of the future state of aquatic ecosystems than when using only a single model (e.g. Nielsen et al. 2014, Trolle et al. 2014). It is evident, however, that the existing models, based mainly on experiences from temperate lakes, are currently unable to fully tackle the major shifts in trophic structure and dynamics of the lake ecosystems to be expected when lakes get considerably warmer. Improvements are therefore needed in order to build more reliable models, a task that is challenged by difficulties in obtaining good quality data to parameterize them. There are many ways in which the reliability of mechanistic models may be improved, as reviewed in detail by Mooij et al. (2010) and Robson (2014). The use of bioclimatic models, which are mostly applied to terrestrial environments, to predict changes in the geographical distribution of species as well as the likelihood of biological invasions under the projected climate change scenarios (Jeschke \& Strayer 2008) should ideally also incorporate biotic interactions (Fernandes et al. 2013). However, in many cases, basic niche information for several species is completely lacking, currently preventing this task. Besides, projecting distribution changes by present niche characteristics might not always result in a reliable prediction, as even in the short term the flora and fauna may adapt to the new conditions, in part by microevolution.

\subsection{Ways to mitigate the effects of climate change}

As many of the symptoms of warming are similar to those following from enhanced nutrient loading (e.g. Trolle et al. 2011), measures should be aimed at increasing the natural resilience of ecosystems against external perturbations (Moss et al. 2011). Measures taken to reduce the nutrient input to freshwaters (Doody et al. 2012), beyond those already implemented or planned, are relatively straightforward and may, among other measures, include: control of fertilizer application rates based on soil retention capacity and crop needs in order to reduce diffuse nutrient losses from cultivated land; establishment of riparian buffer strips to reduce nutrient transfers to water bodies (e.g. Hoffmann et al. 2009, Stutter et al. 2012); re-meandering of channelized streams and (re)establishment of wetlands to increase retention of organic matter and nutrients (e.g. Hoffmann et al. 2011, 2014); improved design of sewage works and rainwater basins to cope with the consequences of flood events and low flows in receiving waters. Special attention should clearly be targeted to modulate the risk of enhanced nutrient loading from catchments during periods of extreme weather events (notably focussing on precipitation and droughtflood effects), which are generally projected to occur more frequently in the future.

However, the needed reduction in external nutrient loadings in the $6^{\circ} \mathrm{C}$ scenario is likely so substantial that it will probably not be possible to obtain a 'good' ecological status according to the European Water Framework Directive (e.g. Nielsen et al. 2014) without substantially interfering with land use and crop production, and this will in particular involve reducing the area allocated to agriculture. Since projections of the global food demand for 2050 and beyond point towards a doubling of the current demand, and given that this is not likely to be satisfied by cultivating new lands (Tilman et al. 2011), there will be increasing pressure on current lands to enhance agricultural outputs. This pressure will be particularly large in the areas of the world which are less impacted by climate change, such as the regions of northern Europe, leading to enhanced nutrient use and losses to the environment (Olesen et al. 2011). The conflicts between the needs to maintain food supply and to maintain good ecological status of lakes (and other natural environments) will thus grow markedly in a much warmer world. Solving these issues would need radical new technologies and changes in human life styles. 


\section{CONCLUSIONS}

We evaluated the impacts of an extreme $6^{\circ} \mathrm{C}$ warming scenario on temperate Danish lakes using a multifaceted modelling approach. We combined an ecohydrological model to estimate future water runoff and catchment nutrient exports with both mechanistic and empirical models, describing key biogeochemical indicators in lakes, which enabled us to quantify the effects of future nutrient loads and air temperature on lake ecosystems. Our model projections suggest that annual water runoff will increase $(46 \%)$, driving also increases in catchment exports of nitrogen and phosphorus (13 and $64 \%$, respectively). The mechanistic and empirical lake modelling approaches both suggest that phytoplankton biomass will increase and that potentially toxin-producing cyanobacteria may become a dominant feature of the phytoplankton community from spring. The food webs within the lakes are also likely to be affected in the direction of higher fish control of algae-grazing water fleas, further reinforcing eutrophication. To be able to mitigate these eutrophication effects, external nutrient loading to the lakes must be reduced considerably. Consequently, compliance with existing legislation, such as the European Union Water Framework Directive, will become increasingly challenging in the future.

Acknowledgements. The present study was funded by a grant from the Danish Council for Strategic Research for the project Centre for Regional Change in the Earth System (CRES - www.cres-centre.dk) under contract no.: DSFEnMi 09-066868, the MARS project (Managing Aquatic ecosystems and water Resources under multiple Stress) funded under the 7th EU Framework Programme, Theme 6 (Environment including Climate Change), contract no.: 603378 (www.mars-project.eu), the Danish projects CIRCE and CLEAR2 (a Villum Kann Rasmussen Centre of Excellence project). We thank Anne Mette Poulsen for valuable editorial comments and Tinna Christensen for figure layout.

\section{LITERATURE CITED}

Andersen HE, Kronvang B, Larsen SE, Hoffmann CC, Jensen TS, Rasmussen EK (2006) Climate-change impacts on hydrology and nutrients in a Danish lowland river basin. Sci Total Environ 365:223-237

Arnold JG, Srinivasan R, Muttiah RS, Williams JR (1998) Large area hydrologic modeling and assessment. I. Model development. J Am Water Resour Assoc 34:73-89

Balayla DJ, Lauridsen TL, Søndergaard M, Jeppesen E (2010) Larger zooplankton in Danish lakes after cold winters: Are fish kills of importance? Hydrobiologia 646: 159-172

Christensen OB, Drews M, Christensen JH, Dethloff $\mathrm{K}$, Ketelsen K, Hebestadt I, Rinke A (2007) The HIRHAM
Regional Climate Model Version 5 ( $\beta$ ). In: DMI Tech Rep, Book 06-17. DMI, Copenhagen

Christensen OB, Yang S, Boberg F, Maule CF and others (2015) Scalability of regional climate change in Europe for high-end scenarios. Clim Res 64:25-38

Collins M, Knutti R, Arblaster J, Dufresne JL and others (2013) Long-term climate change: projections, commitments and irreversibility. In: Stocker TF, Qin D, Plattner G-K, Tignor M and others (eds) Climate change 2013: the physical science basis. Contribution of Working Group I to the Fifth Assessment Report of the Intergovernmental Panel on Climate Change. Cambridge University Press, Cambridge

> Déqué M, Rowell D, Lüthi D, Giorgi F and others (2007) An intercomparison of regional climate simulations for Europe: assessing uncertainties in model projections. Clim Change 81:53-70

> Doltra J, Lægdsmand M, Olesen JE (2014) Impacts of projected climate change on productivity and nitrogen leaching of crop rotations in arable and pig farming systems in Denmark. J Agric Sci 152:75-92

> Doody DG, Archbold M, Foy B, Flynn R (2012) Approaches to the implementation of the Water Framework Directive: targeting measures at critical source areas of diffuse pollution in Irish catchments. J Environ Manag 93: 225-234

Elliott JA (2010) The seasonal sensitivity of cyanobacteria and other phytoplankton to changes in flushing rate and water temperature. Glob Change Biol 16:864-876

$>$ Elsgaard L, Børgesen CD, Olesen JE, Siebert S and others (2012) Shifts in comparative advantages for maize, oat, and wheat cropping under climate change in Europe. Food Addit Contam A 29:1514-1526

Fernandes JA, Cheung WWL, Jennings S, Butenschön M and others (2013) Modelling the effects of climate change on the distribution and production of marine fishes: accounting for trophic interactions in a dynamic bioclimate envelope model. Glob Chang Biol 19:2596-2607

Gliwicz ZM (2003) Between hazards of starvation and risk of predation: the ecology of offshore animals. In: Kinne $\mathrm{O}$ (ed) Excellence of ecology, Book 12. International Ecology Institute, Oldendorf/Luhe

Gyllström M, Hansson LA, Jeppesen E, Garcia-Criado F and others (2005) The role of climate in shaping zooplankton communities of shallow lakes. Limnol Oceanogr 50: 2008-2021

> Hamilton DP, Schladow SG (1997) Prediction of water quality in lakes and reservoirs. 1. Model description. Ecol Modell 96:91-110

Hazeleger W, Wang X, Severijns C, Ştefănescu S and others (2012) EC-Earth V2.2: description and validation of a new seamless earth system prediction model. Clim Dyn 39:2611-2629

Henriksen HJ, Troldborg L, Nyegaard P, Sonnenborg TO, Refsgaard JC, Madsen B (2003) Methodology for construction, calibration and validation of a national hydrological model for Denmark. J Hydrol (Amst) 280:52-71

> Hoffmann CC, Kjaergaard C, Uusi-Kämppä J, Hansen HCB, Kronvang B (2009) Phosphorus retention in riparian buffers: review of their efficiency. J Environ Qual 38: 1942-1955

Hoffmann CC, Kronvang B, Audet J (2011) Restoration and monitoring of nutrient buffering capacities in Danish riparian wetlands. Hydrobiologia 674:5-24

Hoffmann CC, Brix H, Kronvang B (2014) SWS European 
Chapter Meeting on wetland restoration-challenges and opportunities. Ecol Eng 66:1-5

> Jackson LJ, Søndergaard M, Lauridsen TL, Jeppesen E (2007) A comparison of shallow Danish and Canadian lakes and implications of climate change. Freshw Biol 52: 1782-1792

> Janse JH (1997) A model of nutrient dynamics in shallow lakes in relation to multiple stable states. Hydrobiologia 342-343:1-8

Jeppesen E, Kristensen P, Jensen JP, Søndergaard M, Mortensen E, Lauridsen TL (1991) Recovery resilience following a reduction in external phosphorus loading of shallow, eutrophic Danish lakes: duration, regulating factors and methods for overcoming resilience. Mem Ist Ital Idrobiol 48:127-148

Jeppesen E, Jensen JP, Søndergaard M, Lauridsen TL, Pedersen LJ, Jensen L (1997) Top-down control in freshwater lakes: the role of nutrient state, submerged macrophytes and water depth. Hydrobiologia 342/343:151-164

> Jeppesen E, Jensen JP, Søndergaard M, Lauridsen T, Landkildehus F (2000) Trophic structure, species richness and biodiversity in Danish lakes: changes along a phosphorus gradient. Freshw Biol 45:201-213

> Jeppesen E, Kronvang B, Meerhoff M, Søndergaard M and others (2009) Climate change effects on runoff, catchment phosphorus loading and lake ecological state, and potential adaptations. J Environ Qual 38:1930-1941

> Jeppesen E, Meerhoff M, Holmgren K, González-Bergonzoni I and others (2010) Impacts of climate warming on lake fish community structure and potential effects on ecosystem function. Hydrobiologia 646:73-90

> Jeppesen E, Kronvang B, Olesen JE, Audet J and others (2011) Climate change effects on nitrogen loading from cultivated catchments in Europe: implications for nitrogen retention, ecological state of lakes and adaptation. Hydrobiologia 663:1-21

> Jeppesen E, Søndergaard M, Lauridsen TL, Davidson TA and others (2012) Biomanipulation as a restoration tool to combat eutrophication: recent advances and future challenges. Adv Ecol Res 47:411-487

> Jeppesen E, Meerhoff M, Davidson TA, Søndergaard M and others (2014) Climate change impacts on lakes: an integrated ecological perspective based on a multi-faceted approach, with special focus on shallow lakes. J Limnol 73:84-107

> Jeschke JM, Strayer DL (2008) Usefulness of bioclimatic models to study climate change and invasive species. Ann NY Acad Sci 1134:1-24

Jöhnk KD, Huisman J, Sharples J, Sommeijer B, Visser PM, Stroom JM (2008) Summer heatwaves promote blooms of harmful cyanobacteria. Glob Change Biol 14: 495-512

Karlsson IB, Sonnenborg TO, Seaby LP, Jensen KH, Refsgaard JC (2015) Effect of a high-end $\mathrm{CO}_{2}$-emission scenario on hydrology. Clim Res 64:39-54

> Kosten S, Huszar VLM, Bécares E, Costa LS and others (2012) Warmer climate boosts cyanobacterial dominance in lakes. Glob Change Biol 18:118-126

Meerhoff M, Teixeira-de Mello F, Kruk C, Alonso C and others (2012) Environmental warming in shallow lakes: a review of effects on community structure as evidenced from space-for-time substitution approaches. Adv Ecol Res 46:259-350

Mooij WM, Trolle D, Jeppesen E, Arhonditsis G and others (2010) Challenges and opportunities for integrating lake ecosystem modelling approaches. Aquat Ecol 44: 633-667

- Moss B, Kosten S, Meerhoff M, Battarbee RW and others (2011) Allied attack: climate change and eutrophication. Inland Waters 1:101-105

Nakicenovic N, Alcamo J, Davis G, de Vries B and others (2000) Emission scenarios. In: Nakicenovic N, Swart R (eds) Emission scenarios. Cambridge University Press, Cambridge

Nielsen A (2013) Predicting the future state of freshwater lake ecosystems influenced by climate and land-use changes. PhD thesis, Aarhus University

Nielsen A, Trolle D, Bjerring R, Søndergaard M, Olesen JE, Jeppesen E (2014) Effects of climate and nutrient load on the water quality of shallow lakes assessed through ensemble runs by PCLake. Ecol Appl 24:1926-1944

OECD (Organisation for Economic Co-operation and Development) (1982) Eutrophication of waters. Monitoring, Assessment and Control. Rep OECD, Paris

> Olesen JE, Trnka M, Kersebaum KC, Skjelvåg AO and others (2011) Impacts and adaptation of European crop production systems to climate change. Eur J Agron 34: 96-112

Olesen JE, Børgesen CD, Elsgaard L, Palosuo T and others (2012) Changes in flowing and maturity time of cereals in Northern Europe under climate change. Food Addit Contam 29:1527-1542

Patil R, Lægdsmand M, Olesen JE, Porter JR (2012) Sensitivity of crop yield and $\mathrm{N}$ losses in winter wheat to changes in mean and variability of temperature and precipitation in Denmark using the FASSET model. Acta Agric Scand B 62:335-351

> Piani C, Haerter JO, Coppola E (2010) Statistical bias correction for daily precipitation in regional climate models over Europe. Theor Appl Climatol 99:187-192

> Refsgaard JC, Madsen H, Andréassian V, Arnbjerg-Nielsen $\mathrm{K}$ and others (2014) A framework for testing the ability of models to project climate change and its impacts. Clim Change 122:271-282

Robson B (2014) State of the art in modelling of phosphorus in aquatic systems: review, criticisms and commentary. Environ Model Softw 61:339-359

Rolighed J (2013) Climate change makes re-oligotrophication more difficult: a PCLake model study of shallow, Danish Lake Søbygaard. MSc thesis, Aarhus University

Ruuhijärvi J, Rask M, Vesala S, Westermark A, Olin M, Keskitalo J, Lehtovaara A (2010) Recovery of the fish community and changes in the lower trophic levels in a eutrophic lake after a winter kill of fish. Hydrobiologia 646:145-158

> Seaby LP, Refsgaard JC, Sonnenborg TO, Stisen S, Christensen $\mathrm{JH}$, Jensen KH (2013) Assessment of robustness and significance of climate change signals for an ensemble of distribution-based scaled climate projections. J Hydrol (Amst) 486:479-493

Smith P, Olesen JE (2010) Synergies between mitigation of, and adaptation to, climate change in agriculture. J Agric Sci 148:543-552

Søndergaard M, Bjerring R, Jeppesen E (2013) Persistent internal phosphorus loading during summer in shallow eutrophic lakes. Hydrobiologia 710:95-107

Stutter MI, Chardon W, Kronvang B (2012) Riparian buffer strips as a multifunctional management tool in agricultural landscapes: introduction. J Environ Qual 41:297-303

Tilman D, Balzer C, Hill J, Befort BL (2011) Global food 
demand and the sustainable intensification of agriculture. Proc Natl Acad Sci 108:20260-20264

Trolle D, Hamilton DP, Pilditch CA, Duggan IC, Jeppesen E (2011) Predicting the effects of climate change on trophic status of three morphologically varying lakes: implications for lake restoration and management. Environ Model Softw 26:354-370

Trolle D, Elliott A, Mooij WM, Janse JH, Bolding K, Hamilton DP, Jeppesen E (2014) Advancing projections of phytoplankton responses to climate change through ensemble modelling. Environ Modell Softw 61:371-379

Submitted: June 16, 2014; Accepted: November 26, 2014 van der Linden P, Mitchell JFB (2009) ENSEMBLES: climate change and its impacts. Summary of research and results from the ENSEMBLES project. Met Office Hadley Centre, Exeter

> van Vuuren D, Edmonds J, Kainuma M, Riahi K and others (2011) The representative concentration pathways: an overview. Clim Change 109:5-31

Williamson CE, Dodds W, Kratz TK, Palmer MA (2008) Lakes and streams as sentinels of environmental change in terrestrial and atmospheric processes. Front Ecol Environ 6:247-254

Proofs received from author(s): March 27, 2015 